Being Human 
This page intentionally left blank 


\section{Being Human}

Ethics, Environment, and

Our Place in the World

Anna L. Peterson 
This book is a print-on-demand volume. It is manufactured using toner in place of ink. Type and images may be less sharp than the same material seen in traditionally printed University of California Press editions.

University of California Press

Berkeley and Los Angeles, California

University of California Press, Ltd.

London, England

(C) 200 I by

The Regents of the University of California

Library of Congress Cataloging-in-Publication Data

Peterson, Anna Lisa, I963-

Being human : ethics, environment, and our place in the world / Anna L. Peterson.

p. $\mathrm{cm}$.

Includes bibliographical references and index.

ISBN 0-520-22654-2 (hardcover : alk. paper)ISBN o-520-22655-0 (pbk. : alk. paper)

I. Ethics. 2. Environmental ethics. I. Title.

BJIOI2.P454 $200 \mathrm{I}$

I79'.I-de2I

$00-055170$

Printed in the United States of America

The paper used in this publication is both acid-free and totally chlorine-free (TCF). It meets the minimum requirements of ANSI/NISO Z39.48-I984 (R 1997) (Permanence of Paper).

The fragment from the poem "Animal of Light," from Winter Garden (C) 1986 by Pablo Neruda, William O'Daly trans., is reprinted by permission of Copper Canyon Press, P.O. Box 27I, Port Townsend, WA 98368 .

A different version of chapter 3 was published as "Environmental Ethics and the Social Construction of Nature," Environmental Ethics 2I, no. 4 (winter I999): 339-57. 
For my family, by nature and by nurture, and especially for Gabriel, animal de luz 
Soy en este sin fin sin soledad un animal de luz acorralado por sus errores y por su follaje

I am in this endless lack of solitude an animal of light corralled by his mistakes and by his foliage Pablo Neruda, "Animal de Luz" 